\title{
Cucurbit Rootstocks Resistant to Fusarium oxysporum f. sp. niveum Remain Resistant When Coinfected by Meloidogyne incognita in the Field
}

\author{
Anthony P. Keinath, ${ }^{1 \dagger}$ W. Patrick Wechter, ${ }^{2}$ William B. Rutter, ${ }^{2}$ and Paula A. Agudelo ${ }^{1}$ \\ ${ }^{1}$ Department of Plant and Environmental Sciences, Clemson University, Clemson, SC 29634-0310; and ${ }^{2}$ Agricultural Research \\ Service, U.S. Vegetable Laboratory, U.S. Department of Agriculture, Charleston, SC 29414-5329
}

Abstract

\begin{abstract}
Interspecific hybrid squash (Cucurbita maxima $\times$ Cucurbita moschata) rootstocks used to graft watermelon (Citrullus lanatus var. lanatus) are resistant to Fusarium oxysporum f. sp. niveum, the fungus that causes Fusarium wilt of watermelon, but they are susceptible to Meloidogyne incognita, the southern root knot nematode. A new citron (Citrullus amarus) rootstock cultivar Carolina Strongback is resistant to $F$. oxysporum $\mathrm{f}$. sp. niveum and $M$. incognita. The objective of this study was to determine if an interaction between $M$. incognita and $F$. oxysporum $\mathrm{f}$. sp. niveum race 2 occurred on grafted or nongrafted triploid watermelon susceptible to F. oxysporum f. sp. niveum race 2. In 2016 and 2018, plants of nongrafted cultivar Fascination and Fascination grafted onto Carolina Strongback and interspecific hybrid squash cultivar Carnivor were inoculated or not inoculated with $M$. incognita before transplanting into field plots infested or not infested with $F$. oxysporum $\mathrm{f}$. sp. niveum race 2 . Incidence of Fusarium wilt and area under the disease progress curve did not differ when hosts were inoculated with $F$. oxysporum $\mathrm{f}$. sp. niveum
\end{abstract}

alone or F. oxysporum f. sp. niveum and M. incognita together. Fusarium wilt was greater on nongrafted watermelon ( $78 \%$ mean incidence) than on both grafted rootstocks and lower on Carnivor (1\% incidence) than on Carolina Strongback (12\% incidence; $P \leq 0.01$ ). Plants not inoculated with $F$. oxysporum $\mathrm{f}$. sp. niveum did not wilt. At the end of the season, Carnivor had a greater percentage of the root system galled than the other two hosts, whereas galling did not differ on Fascination and Carolina Strongback. $F$. oxysporum f. sp. niveum reduced marketable weight of nongrafted Fascination with and without coinoculation with $M$. incognita. $M$. incognita reduced marketable weight of Fascination grafted onto Carnivor compared with noninoculated, nongrafted Fascination. In conclusion, cucurbit rootstocks that are susceptible and resistant to $M$. incognita retain resistance to $F$. oxysporum $\mathrm{f}$. sp. niveum when they are coinfected with $M$. incognita.

Keywords: disease management, fungi, nematodes, vegetables, yield loss and economic impacts
Fusarium wilt of watermelon (Citrullus lanatus [Thunb.] Matsum. \& Nakai var. lanatus) is caused by Fusarium oxysporum Schltdl.: Fr. f. sp. niveum. Four races, designated race 0 , race 1 , race 2 , and race 3 , have been reported, and race 2 is currently the most widely distributed and damaging race (Martyn 2017). Although sources of resistance to race 2 have been identified in citron (Citrullus amarus Schrad., syn. C. lanatus var. citroides), resistant watermelon cultivars are not yet available (Branham et al. 2017; Wechter et al. 2012). Triploid watermelon cultivar Fascination, which is intermediately resistant to race 1 and produces oblong, striped fruits that average $6.8 \mathrm{~kg}$ apiece, is widely grown in fields infested with $F$. oxysporum f. sp. niveum (Keinath and Hassell 2014b; Keinath et al. 2019; Kemble et al. 2018). In the absence of watermelon cultivars resistant to Fusarium wilt caused by race 2, grafting susceptible cultivars onto interspecific hybrid squash rootstocks (Cucurbita maxima Duchesne ex Lam. $\times$ Cucurbita moschata Duchesne ex Poir) protects grafted scions from Fusarium wilt (Davis et al. 2008; Keinath and Hassell 2014b; Miguel et al. 2004). Interspecific hybrid squash possesses nonhost resistance to $F$. oxysporum $\mathrm{f}$. sp. niveum races 1 and 2 (Keinath and Hassell 2014a; Yetisir et al. 2003). Thus, grafting is effective regardless of which race is present or predominates in a field.

Watermelon and interspecific hybrid squash are susceptible to Meloidogyne incognita (Kofoid \& White, 1919) Chitwood, 1949,

${ }^{\dagger}$ Corresponding author: A. P. Keinath; tknth@clemson.edu

Funding: This material is based on work that is supported in part by National Institute of Food and Agriculture, U.S. Department of Agriculture award 2016-51181-25404 and projects SC-1700536 and SC-1700522.

The author(s) declare no conflict of interest.

Accepted for publication 1 December 2018.

(c) 2019 The American Phytopathological Society the Southern root knot nematode. In general, interspecific hybrid squash is more susceptible to galling than watermelon (ÁlvarezHernández et al. 2015; Thies et al. 2010, 2015a, 2015b). In addition, watermelon plants grafted onto interspecific hybrid squash and grown in root knot-infested soil produced significantly less total fruit by weight than nongrafted watermelon (Thies et al. 2010, 2015a, 2015b). Thus, simply adopting grafting onto interspecific hybrid squash rootstocks to manage Fusarium wilt could lead to problems caused by root knot nematodes.

A potential interaction between $M$. incognita and $F$. oxysporum f. sp. niveum on watermelon was investigated in three previous greenhouse studies. Using field soils collected in Georgia in the United States, Sumner and Johnson (1973) reported that mean wilt incidence was greater in soils naturally infested with both pathogens than with only $F$. oxysporum $\mathrm{f}$. sp. niveum race 1 , although the difference was not analyzed statically. Approximately one-third of the samples that they characterized as being infested with $M$. incognita had very low galling on watermelon at the end of the assays. Nevertheless, $t$ tests that we calculated with means from table 1 of Sumner and Johnson (1973) showed a significantly $(P \leq 0.03)$ greater incidence of Fusarium wilt in soils infested with root knot nematode than in soils not infested or soils with very low infestation. In a greenhouse study in Korea, no differences in Fusarium wilt severity were observed when watermelon or interspecific hybrid squash was inoculated with $F$. oxysporum f. sp. niveum or $F$. oxysporum f. sp. niveum plus $M$. incognita. The race of the $F$. oxysporum $\mathrm{f}$. sp. niveum isolate used and the resistance of the single watermelon cultivar tested were not reported (Seo and Kim 2017). In our previous greenhouse study, no increase in wilt incidence, wilt severity, or recovery of $F$. oxysporum from wilted plants was observed between treatments inoculated with $F$. oxysporum $\mathrm{f}$. sp. niveum alone or $F$. oxysporum $\mathrm{f}$. sp. niveum plus $M$. incognita race 3 (Keinath and Agudelo 2018). No change in susceptibility to Fusarium wilt was observed on watermelon cultivar Tri-X 313 susceptible to all races of $F$. oxysporum f. sp. niveum, Fascination intermediately resistant to race 1 and susceptible to race 2 , or interspecific hybrid squash cultivar Strong Tosa. Results of these three greenhouse studies are not in agreement. More 
importantly, the potential for root knot nematode to increase incidence of Fusarium wilt needs to be tested in field trials. In addition, the lack of an interaction between $F$. oxysporum $\mathrm{f}$. sp. niveum and $M$. incognita for wilt incidence and severity in the greenhouse may not hold for fruit yields in the field. Although both pathogens can reduce yields of susceptible watermelon cultivars, it is unknown if coinfection decreases yields more than infection with only one of these pathogens.

Various plant introduction lines of citron have resistance to $F$. oxysporum f. sp. niveum and M. incognita (Branham et al. 2017; Thies et al. 2015a, 2015b, 2016; Wechter et al. 2016). Cultivar Carolina Strongback, which is a cross of U.S. Vegetable Laboratory (USVL) 246 and USVL252, two citron selections with resistance to $F$. oxysporum f. sp. niveum races 1 and 2, has been tested as a Fusarium wilt-resistant rootstock for watermelon (Smith and Freeman 2017; Wechter et al. 2016). Based on a preliminary screening, Carolina Strongback (previously named cultivar Bulldog) and its parents have resistance to M. incognita (Smith et al. 2017). A rootstock that is resistant to both $F$. oxysporum $\mathrm{f}$. sp. niveum race 2 and $M$. incognita would offer similar benefits provided by interspecific hybrid squash rootstocks without the drawbacks of susceptibility to root knot nematodes. The objectives of this study were (i) to determine if infection by $M$. incognita of watermelon and rootstocks used to graft watermelon reduces their resistance to $F$. oxysporum $\mathrm{f}$. sp. niveum race 2 in the field, (ii) to determine if coinoculation with $F$. oxysporum f. sp. niveum race 2 and $M$. incognita reduces watermelon yields, and (iii) to compare a new hybrid citron rootstock with an interspecific hybrid squash rootstock.

\section{Materials and Methods}

Field plot establishment and maintenance. Experiments were done at the Clemson University Coastal Research and Education Center (CREC) in Charleston, South Carolina $\left(32.47304^{\circ} \mathrm{N}\right.$, $80.41116^{\circ} \mathrm{W}$ ) in spring 2016 and spring 2018. The soil type in the field used in both years is Yonges loamy fine sand. The field was cropped to peanut in 2015 and sunflower in 2017, and it was seeded to rye in the fall before both experiments. In each year, the field was disked twice, and $560 \mathrm{~kg} / \mathrm{ha}$ of $15 \mathrm{~N}-0 \mathrm{P}-12.5 \mathrm{~K}$ fertilizer was applied to rows. Raised beds were shaped $0.9-\mathrm{m}$ wide on $2.7-\mathrm{m}$ centers, sprayed with the preemergent herbicides halosulfuron methyl and fomesafen in 2016 and $S$-metolachlor and halosulfuron methyl in 2018, and covered with black polyethylene mulch on 15 March 2016 and 15 March 2018. The herbicides $S$-metolachlor and pendimethalin were applied between rows in 2016, and fomesafen was applied between rows in 2018 .

The experimental design in both years was a split plot with four replications. The main plot treatment was rootstock, and the subplot treatment was pathogen inoculation. The three rootstock treatments were nongrafted triploid watermelon Fascination, Fascination grafted onto interspecific hybrid squash cultivar Carnivor, and Fascination grafted onto hybrid citron Carolina Strongback (Table 1). Seeds of Fascination (Syngenta Seeds, Woodland, CA) were sown on 23 February 2016 and 14 February 2018 into 98-cell trays containing Fafard 3B potting mix (Sun Gro Horticulture, Agawam, MA). Rootstocks Carnivor (Syngenta Seeds) and Carolina Strongback (provided by W. P. Wechter) were sown on 26 February 2016 and 12 February 2018. Scions and rootstocks were grafted with the one cotyledon grafting method on 21 March 2016 and 2 March 2018 (Davis et al. 2008). Grafted plants were placed in a healing chamber with $90 \%$ relative humidity for 1 week and then transferred to a greenhouse until transplanting.

One day before transplanting, seedlings in trays were drenched with propamocarb hydrochloride $(0.72 \mathrm{~g} / \mathrm{liter})$ to reduce Pythium stem and root rot after transplanting. Seedlings were transplanted on 6 April 2016 and 3 April 2018 into single-row field plots 12.2-m long, with 12 plants per plot spaced $1.1 \mathrm{~m}$ apart. Plots were separated by 2.4-m nonplanted space within rows. Five SP-6 pollenizers (Syngenta Seeds) were transplanted per plot: one at each end and one between every third plant. Two days after transplanting in 2018, mefenoxam $(1.12 \mathrm{~kg} / \mathrm{ha})$ was applied through the drip irrigation system to reduce Pythium stem and root rot. Liquid 7N-7P-1K fertilizer with minor elements was applied to the field throughout the season through the drip irrigation system. Fertilizer rate was adjusted during the growing season based on the watermelon growth stage (Keinath et al. 2010).

Currently registered fungicides were applied every 7 days for 5 and 8 weeks in 2016 and 2018, respectively, to prevent powdery mildew. In 2016, two applications of cyflufenamid were rotated with two applications of quinoxyfen followed by one application of penthiopyrad. In 2018, three applications of metrafenone were rotated with two applications of quinoxyfen followed by one application each of cyflufenamid and triflumizole. In 2016, gummy stem blight was managed with two applications of chlorothalonil followed by one application of cyprodinil plus fludioxonil applied biweekly. In 2018, anthracnose was managed with five applications of mancozeb, two applications of azoxystrobin, and one application of pyraclostrobin applied weekly. Plots were checked for arthropods, and miticides (fenpyroximate and acequinocyl in 2016 and acequinocyl and abamectin in 2018) and insecticides (bifenthrin in both years and chlorantraniliprole in 2018) were applied when two-spotted spider mites, aphids, and cucumber beetles were observed in both years or when armyworms were observed in 2018 (Kemble et al. 2018).

Pathogen inoculations. In 2016, F. oxysporum f. sp. niveum race 2 isolate B05-30-C1, which was collected in 2005 at the CREC, was used, and in 2018, race 2 isolates B05-30-C1 and A08-12, which were collected in 2008 from a commercial farm in Hampton County, South Carolina, were used (Keinath and DuBose 2009; Keinath and Hassell 2009). Wheat seed inoculum as described by Liu et al. (2017) was prepared by autoclaving $100 \mathrm{~g}$ wheat seed in $50 \mathrm{ml}$ deionized water in tissue culture boxes three times on successive days. Three agar discs cut from a 7-day-old culture on quarter-strength potato dextrose agar (QPDA) were added to each tissue culture box. Colonized grain was incubated at $22^{\circ} \mathrm{C}$ for 14 days, dried in a fume hood for 15 days, and stored at $22^{\circ} \mathrm{C}$ until use. In 2018, grain was inoculated separately with the two isolates and mixed 1:1 after drying. Before mixing, 50 dried seeds colonized by each isolate were cultured on QPDA, and $100 \%$ of the seeds in both samples were colonized by F. oxysporum. Inoculum, $18 \mathrm{~g}$ in 2016 and $27 \mathrm{~g}$ in 2018, was added to the transplanting holes immediately before transplants were set. In 2018 , to more evenly distribute the inoculum, an additional $320 \mathrm{~g}$

Table 1. Cucurbit cultivars tested for susceptibility to Fusarium oxysporum f. sp. niveum and Meloidogyne incognita in the field in Charleston, South Carolina in 2016 and 2018

\begin{tabular}{|c|c|c|c|c|c|c|}
\hline \multirow[b]{2}{*}{ Cultivar } & \multirow[b]{2}{*}{ Common name } & \multirow[b]{2}{*}{ Latin binomial } & \multirow[b]{2}{*}{ Grafting } & \multirow[b]{2}{*}{ Source } & \multicolumn{2}{|c|}{ Reaction to inoculation } \\
\hline & & & & & $\begin{array}{c}\text { F. oxysporum } \\
\text { f. sp. niveum race } 2\end{array}$ & M. incognita \\
\hline Fascination & Triploid watermelon & Citrullus lanatus & Scion & Syngenta & Susceptible & Moderately susceptible \\
\hline Carnivor & $\begin{array}{l}\text { Interspecific hybrid } \\
\text { squash }\end{array}$ & $\begin{array}{l}\text { Cucurbita maxima } \times \\
\text { Cucurbita moschata }\end{array}$ & Rootstock & Syngenta & Resistant & Highly susceptible \\
\hline $\begin{array}{l}\text { Carolina } \\
\text { Strongback }\end{array}$ & Hybrid citron & Citrullus amarus & Rootstock & $\mathrm{USDA}, \mathrm{USVL}^{\mathrm{a}}$ & Resistant & Moderately resistant \\
\hline
\end{tabular}

${ }^{a}$ USDA, U.S. Department of Agriculture, USVL, U.S. Vegetable Laboratory. 
of inoculum was spread in infested plots on 14 March and incorporated with a rototiller before mulch was laid.

In 2016, roots of seedlings were inoculated with $M$. incognita race 3 , which was originally isolated from a field cropped to soybean and cotton in Barnwell County, South Carolina, and maintained on tomato cultivar Rutgers in a greenhouse. One day before inoculation, galled roots were cut into $1-\mathrm{cm}$-long pieces and agitated for $4 \mathrm{~min}$ in $0.5 \% \mathrm{NaOCl}$ (Hussey and Barker 1973). The mix was poured through two stacked sieves with 75 - and $25-\mu \mathrm{m}$ openings. Eggs retained on the $25-\mu \mathrm{m}$ sieve were suspended in water at a concentration of 2,000 eggs per $1 \mathrm{ml}$. The nematode suspension was applied to seedlings in the nematode treatments by depositing $1 \mathrm{ml}$ suspension into each transplant cell the morning of transplanting. Water was applied to the seedlings not receiving $M$. incognita inoculum.

In 2018, roots were inoculated with an isolate of $M$. incognita race 3 originally isolated from a vegetable production field in Charleston County, South Carolina and maintained on tomato cultivar Brandywine in a greenhouse. Four days before inoculation, eggs were extracted from heavily infected tomato roots using the $1 \% \mathrm{NaOCl}$ method (Hussey and Barker 1973). Nematode eggs were further cleaned by differential centrifugation in a $35 \%$ sucrose solution and then washed with tap water to remove excess sucrose. To induce hatching, nematode eggs were placed on a $31-\mu \mathrm{m}$ nylon mesh membrane that was immersed in $50 \mathrm{ml} 10 \mathrm{mM} \mathrm{2-}$ ethanesulfonic acid (MES) buffer (pH 6.5) and incubated at $28^{\circ} \mathrm{C}$. Freshly hatched second-stage juvenile nematodes (J2s) were collected every $24 \mathrm{~h}$ and stored at $4^{\circ} \mathrm{C}$ until the day of inoculation. On the day of inoculation, $5.3 \times 10^{5}$ live $\mathrm{J} 2 \mathrm{~s}$ were counted, combined with $4.7 \times 10^{5}$ freshly extracted eggs, and suspended in tap water to a final concentration of $600 \mathrm{~J} 2 \mathrm{~s}$ plus eggs per $1 \mathrm{ml}$. The day before transplanting, each seedling in the nematode treatments was inoculated with $2 \mathrm{ml}$ nematode suspension applied into each transplant cell. Water was applied to the seedlings not receiving $M$. incognita inoculum.

Data collection and analysis. Incidence of Fusarium wilt was determined eight times each year on a weekly interval from 2 to 9 weeks after transplanting: from 20 April to 8 June 2016 and from 18 April to 5 June 2018. Fusarium wilt symptoms were assessed as the percentage of plants per plot with visible symptoms of wilting on at least two adjacent lower leaves on one or more, but rarely all, vines of a plant. Plants affected with Pythium stem rot were excluded from the dataset (Keinath et al. 2019). Incidence expressed as a proportion was used to calculate area under the disease progress curve (AUDPC) (Shaner and Finney 1977).

In selected treatments, the length of one vine on each of three symptomless plants per plot was measured on 11 May 2016 and 3 May 2018, 5 and 4 weeks after transplanting, respectively. Vine lengths on nongrafted Fascination plants were measured in the four pathogen treatments to assess the effects of pathogens on the vigor of a susceptible host. Vine lengths were measured in the three noninoculated rootstock treatments to assess rootstock vigor in the absence of introduced pathogens. Plants were selected by starting with the second plant on the south end of the plot and then choosing every other plant. If fewer than three plants per plot were healthy, then diseased plants were also measured. A vine growing toward the south was selected on each plant.

Mature fruit, identified as fruit on which the tendril associated with the leaf growing at the point of attachment of the peduncle to the vine had died, was harvested six times at weekly intervals from 21 June to 26 July 2016 and from 26 June to 31 July 2018 (Miguel et al. 2004). All fruits were counted, weighed, and graded as unblemished, sunburned, damaged by wildlife, or affected with anthracnose fruit rot (United States Department of Agriculture, Agriculture Marketing Service 2006). Unblemished fruits that weighed $\geq 4.54 \mathrm{~kg}$ were considered marketable (Keinath et al. 2019). Unblemished fruits between 2.27 and $4.53 \mathrm{~kg}$ were considered too small to be marketable. Sunburned, damaged, and diseased fruits were considered cull fruit. Weights of marketable fruits were sorted into four categories based on standard marketing size categories for triploid watermelon, except that a threshold weight of 4.54 instead of $4.08 \mathrm{~kg}$ was used: small (60 count), 4.54 to
$6.12 \mathrm{~kg}$; medium (45 count), 6.17 to $7.94 \mathrm{~kg}$; large (36 count), 7.98 to $9.75 \mathrm{~kg}$; and extra large (30 count), $\geq 9.8 \mathrm{~kg}$ (Bertucci et al. 2018).

After the last harvest, the third and seventh plants from the south end of each plot were dug with root systems intact. Roots were washed under running water, and the percentage area covered with galls was rated on a scale from 0 to $100 \%$ in $10 \%$ increments on 27 July 2016 and 13 August 2018. Roots were blotted to remove excess moisture and weighed.

Mixed model maximum likelihood analysis of variance was done with SAS PROC GLIMMIX (SAS, version 9.4; SAS, Inc., Cary, NC) with the Gaussian response distribution. Year, rootstock, pathogen inoculation, and all interactions among these factors were considered fixed effects, and block was a random effect. In models that included data from 2 years, a split-split plot was used, with year as the whole plot, rootstock treatment as the split plot, pathogen treatment as the split-split plot, and block within year and block within year by rootstock as the random effects. Progression of disease incidence over time, measured as days after transplanting, was examined with repeated measures analysis of variance in PROG GLM (Madden 1986). Fruit size distribution, expressed as a percentage of all marketable-sized fruit, was examined with multivariate analysis of variance in PROC GLM (Keinath et al. 2019). Model fits were assessed by evaluating plots of residuals for normality. Disease incidence was transformed before analysis by calculating the arcsine of the square root, AUDPC was transformed by calculating the square root, and weight of cull fruit and fresh weight of roots were transformed by calculating the base 10 logarithm. Other variables did not need transformations to normalize the residuals. When interaction terms in models were significant (i.e., had a probability value $\leq$ 0.05), the SLICE option of the LSMEANS statement was used to test levels of one treatment within levels of another treatment. When a rootstock by pathogen interaction was significant in the analysis of yield data, single-degree of freedom interaction contrasts were written to compare means of pathogen inoculation treatment levels. When there was no interaction of year with rootstock or pathogen treatment, treatment means were calculated across both years. Treatment means were separated with Fisher's protected least significant difference test.

\section{Results}

Fusarium wilt. Rootstocks and pathogen treatments affected the progress and the final level of Fusarium wilt very similarly in both years, because there were no significant effects of year $(P \geq 0.41)$ or significant interactions with year $(P \geq 0.29)$ for either measurement of disease. The effects of rootstock, pathogen inoculation, and their interaction were highly significant for both final incidence and AUDPC ( $F$ values significant at $P<0.0001)$. Final incidence rates of Fusarium wilt and AUDPC were significantly greater in the treatments in which nongrafted Fascination and Fascination grafted onto Carolina Strongback were inoculated with $F$. oxysporum f. sp. niveum than in the corresponding rootstock treatments not inoculated with $F$. oxysporum f. sp. niveum (Fig. 1 and Table 2). However, disease incidence and AUDPC for Carnivor inoculated with $F$. oxysporum f. sp. niveum alone or $F$. oxysporum f. sp. niveum together with $M$. incognita did not differ from disease incidence on Carnivor not inoculated with $F$. oxysporum $\mathrm{f}$. sp. niveum $(P \geq 0.37)$. Treatments inoculated with $F$. oxysporum $\mathrm{f}$. sp. niveum alone did not differ from treatments coinoculated with $F$. oxysporum $\mathrm{f}$. $\mathrm{sp}$. niveum and $M$. incognita on any rootstock or nongrafted watermelon $(P \geq 0.35)$.

Final incidence rates of Fusarium wilt and AUDPC were highest for the two $F$. oxysporum $\mathrm{f}$. sp. niveum treatments inoculated onto nongrafted Fascination; these two treatments had more severe Fusarium wilt than all other treatments $(P=0.01)$ (Fig. 1 and Table 2). Carolina Strongback, either inoculated with $F$. oxysporum f. sp. niveum alone or $F$. oxysporum f. sp. niveum plus $M$. incognita, had less Fusarium wilt and a lower AUDPC than nongrafted Fascination but more severe disease than all treatments not inoculated with $F$. oxysporum f. sp. niveum and all Carnivor treatments $(P \leq 0.05)$ (Table 2). Disease incidence on plants in the six treatments not 
inoculated with $F$. oxysporum f. sp. niveum and plants in the two Carnivor treatments inoculated with $F$. oxysporum $\mathrm{f}$. sp. niveum was not significantly greater than zero ( $t$ tests, $P \geq 0.14$ ).

Progression of disease incidence over time did not differ between years $(P=0.86)$, and there was no significant interaction of year with rootstock or pathogen treatment $(P \geq 0.41)$. By 4 weeks after transplanting, disease incidence was greater on nongrafted Fascination inoculated with $F$. oxysporum f. sp. niveum, either with or without $M$. incognita, than on all other treatments (Fig. 1). By 6 weeks after transplanting, wilt incidence was greater on grafted Carolina Strongback inoculated with $F$. oxysporum f. sp. niveum than on any grafted Carnivor treatment or any treatment not inoculated with $F$. oxysporum $\mathrm{f}$. sp. niveum. Wilt incidence did not increase significantly over time for any grafted Carnivor treatment or any treatment not inoculated with $F$. oxysporum $\mathrm{f}$. sp. niveum ( $P \geq 0.93$ ).

Plant vigor. Vine length was measured in two subsets of treatments. Vine lengths on nongrafted Fascination were measured in all four pathogen treatments to assess the effects of pathogens on plant vigor. Vine length varied by year and pathogen treatment, but there was no year by treatment interaction $(P=0.71)$. Vines were significantly longer in the two treatments without $F$. oxysporum $\mathrm{f}$. sp. niveum (mean of $76.1 \mathrm{~cm}$ ) than in the two treatments with $F$.

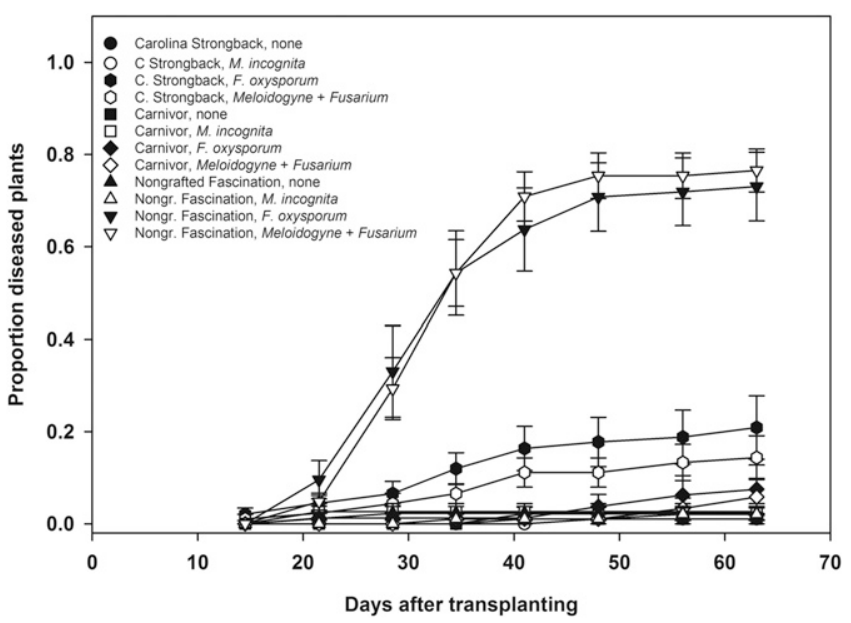

Fig. 1. Progress of Fusarium wilt averaged across field experiments in 2016 and 2018 on triploid watermelon cultivar Fascination inoculated or not inoculated with Meloidogyne incognita and transplanted into plots infested or not infested with Fusarium oxysporum f. sp. niveum race 2. Fascination was not grafted, was grafted onto interspecific hybrid squash rootstock cultivar Carnivor, or was grafted onto citron rootstock cultivar Carolina Strongback. Each data point is the mean of eight replications (four per year) with one standard error of the mean. Nongrafted Fascination treatments differ significantly from all other treatments at all rating dates starting 4 weeks after transplanting $(P<0.01)$. oxysporum f. sp. niveum $(49.4 \mathrm{~cm} ; P \leq 0.04)$. Inoculation with $F$. oxysporum f. sp. niveum reduced mean vine length by $35 \%$. Vines of nongrafted Fascination were twice as long at 35 days after transplanting in $2016(88.8 \mathrm{~cm})$ as at 30 days after transplanting in 2018 (42.2 cm; $P=0.001)$.

Vine lengths were also measured in all noninoculated rootstock treatments to assess rootstock vigor. Vine lengths for nongrafted Fascination and Carnivor were significantly $(P=0.01)$ longer in 2016 than in 2018 (Table 3), but vine lengths for Carolina Strongback did not differ between years (year by rootstock interaction significant, $P=0.001)$. In 2016, vines of nongrafted Fascination and Carnivor were significantly $(P=0.003)$ longer than vines of Carolina Strongback, but vine lengths did not differ among rootstocks in 2018.

Root galling. Galls were observed on 53 and 64 of 96 root systems examined in 2016 and 2018, respectively. Although galled roots occurred both on plants inoculated and on plants not inoculated with $M$. incognita, percentage of galling was greater on inoculated plants than on noninoculated plants. Percentage of galling on nongrafted Fascination and Carolina Strongback roots not inoculated with $M$. incognita was not significantly different from zero $(t$ tests, $P>$ 0.15). In both years, only one noninoculated Carnivor root system had no galls, and the other plants without galls were approximately evenly distributed between Carolina Strongback and Fascination.

There was a significant $(P<0.0001)$ effect of rootstock and pathogen inoculation and a significant interaction between these two factors $(P=0.047)$ on percentage root galling. As with Fusarium wilt measurements, there were no significant effects of year $(P=0.30)$ or significant interactions with year $(P \geq 0.13)$. The rootstockpathogen interaction occurred, because pathogen inoculation treatments did not differ on Carolina Strongback but differed on Carnivor

Table 3. Mean length of vines and mean fresh weight of roots of cultivar Fascination watermelon that was grafted onto two different rootstocks or was not grafted

\begin{tabular}{lcccccc}
\hline & & \multicolumn{2}{c}{$\begin{array}{c}\text { Vine } \\
\text { length }(\mathbf{c m})^{\mathbf{w}}\end{array}$} & & \multicolumn{2}{c}{$\begin{array}{c}\text { Fresh root } \\
\text { weight }(\mathbf{g})^{\mathbf{x}}\end{array}$} \\
\cline { 3 - 4 } Grafting & Rootstock & $\mathbf{2 0 1 6}$ & $\mathbf{2 0 1 8}$ & & $\mathbf{2 0 1 6}$ & $\mathbf{2 0 1 8}$ \\
\hline None & None & $107.6 \mathrm{a}^{\mathrm{y}}$ & $58.4 \mathrm{~b}$ & & $80.5 \mathrm{de}^{\mathrm{z}}$ & $73.3 \mathrm{e}$ \\
Grafted & Cultivar Carnivor & $110.9 \mathrm{a}$ & $53.1 \mathrm{~b}$ & & $179.2 \mathrm{a}$ & $130.2 \mathrm{bc}$ \\
Grafted & Cultivar Carolina & $68.1 \mathrm{~b}$ & $63.8 \mathrm{~b}$ & & $99.5 \mathrm{~cd}$ & $140.8 \mathrm{ab}$ \\
& Strongback & & & & \\
\hline
\end{tabular}

w Vine length was measured 5 and 4 weeks after transplanting in 2016 and 2018, respectively.

x Root weight was measured 16 and 19 weeks after transplanting in 2016 and 2018, respectively.

${ }^{y}$ Lengths with the same letter are not significantly different: Fisher's protected least significant difference test, $P<0.01$.

${ }^{z}$ Weights with the same letter are not significantly different: Fisher's protected least significant difference test, $P<0.05$.

Table 2. Response of grafted or nongrafted cultivar Fascination triploid watermelon to coinoculation with Fusarium oxysporum f. sp. niveum and Meloidogyne incognita in the fieldy

\begin{tabular}{|c|c|c|c|c|c|}
\hline Grafting & Rootstock & Pathogen treatment & Final wilt incidence (\%) & AUDPC & Galling (\%) \\
\hline None & None & None & $0.6 \mathrm{~cd}^{\mathrm{z}}$ & $0.3 \mathrm{~cd}$ & $5.0 \mathrm{c}$ \\
\hline None & None & M. incognita & $0.1 \mathrm{~d}$ & $0.1 \mathrm{~d}$ & $13.8 \mathrm{c}$ \\
\hline None & None & F. oxysporum & $75.9 \mathrm{a}$ & $22.8 \mathrm{a}$ & $2.5 \mathrm{c}$ \\
\hline None & None & M. incognita $+F$. oxysporum & $79.4 \mathrm{a}$ & $24.2 \mathrm{a}$ & $8.3 \mathrm{c}$ \\
\hline Grafted & Cultivar Carnivor & None & $0.1 \mathrm{~d}$ & $0.0 \mathrm{~d}$ & $71.9 \mathrm{~b}$ \\
\hline Grafted & Cultivar Carnivor & M. incognita & $0.7 \mathrm{~cd}$ & $0.3 \mathrm{~cd}$ & $90.6 \mathrm{a}$ \\
\hline Grafted & Cultivar Carnivor & F. oxysporum & $1.6 \mathrm{bcd}$ & $0.3 \mathrm{~cd}$ & $70.0 \mathrm{~b}$ \\
\hline Grafted & Cultivar Carnivor & M. incognita $+F$. oxysporum & $1.2 \mathrm{~cd}$ & $0.2 \mathrm{~d}$ & $93.1 \mathrm{a}$ \\
\hline Grafted & Cultivar Carolina Strongback & None & $0.6 \mathrm{~cd}$ & $0.1 \mathrm{~d}$ & $5.6 \mathrm{c}$ \\
\hline Grafted & Cultivar Carolina Strongback & M. incognita & $0.1 \mathrm{~d}$ & $0.0 \mathrm{~d}$ & $8.8 \mathrm{c}$ \\
\hline Grafted & Cultivar Carolina Strongback & F. oxysporum & $14.4 \mathrm{~b}$ & $4.4 \mathrm{~b}$ & $4.4 \mathrm{c}$ \\
\hline Grafted & Cultivar Carolina Strongback & M. incognita $+F$. oxysporum & $10.5 \mathrm{bc}$ & $2.8 \mathrm{bc}$ & $11.3 \mathrm{c}$ \\
\hline
\end{tabular}

y Field experiments were done in 2016 and 2018. All means were calculated across years, because there were no interactions of year with rootstock or pathogen treatments for any disease measurement. AUDPC, area under the disease progress curve.

${ }^{\mathrm{z}}$ Means within a column with the same letter are not significantly different: Fisher's protected least significant difference test, $P<0.01$. 
and nongrafted Fascination (Table 2). On Carnivor, the mean percentage of galling on inoculated roots was significantly greater than the mean percentage of galling on noninoculated roots $(P<0.0001)$. Carnivor roots inoculated with $M$. incognita had significantly more galling than all other treatments, and noninoculated Carnivor roots had significantly more galling than all roots on nongrafted Fascination and Carolina Strongback $(P \leq 0.0001)$ (Table 2). Galling on root systems of Fascination and Carolina Strongback did not differ significantly among treatments $(P=0.01)$. However, the mean percentage of galling on roots of nongrafted Fascination inoculated with $M$. incognita was greater than on noninoculated Fascination roots (interaction contrast, $P=0.042$ ).

Root fresh weight was not affected by pathogen treatment, but weights differed with rootstock and year (year by rootstock interaction, $P=0.007)$. In 2016, Carnivor root systems weighed more than root systems of nongrafted Fascination and Carolina Strongback, which did not differ from each other $(P=0.05)$ (Table 3). In 2018, roots of Carnivor and Carolina Strongback weighed more than roots of nongrafted Fascination. The heavier weight of Carnivor root systems in both years was primarily because of extensive galling. Within rootstocks, Carnivor roots in 2016 weighed more than Carnivor roots in 2018, whereas Carolina Strongback roots in 2018 weighed more than Carolina Strongback roots in $2016(P=0.05)$.

Fruit yields. Weights of fruits that were of marketable size and quality differed by year, rootstock treatment, and pathogen treatment (three-way interaction significant, $P=0.039$ ), and therefore, the data for the two years were analyzed separately. In 2016, marketable weight of fruit did not differ among any treatments (Tables 4 and $5)$. In 2018 , there was a highly significant rootstock by pathogen interaction $(P=0.0003)$, because marketable weight of Carolina Strongback did not differ among pathogen treatments, but pathogen treatments affected weight of marketable fruit produced by Carnivor and nongrafted Fascination (Tables 4 and 5). Mean numbers of marketable fruit, which ranged from 2,471 to 3,905 fruit per 1 ha in the different pathogen treatments, did not differ among rootstock or pathogen treatments in either year (data not shown).

In 2018, nongrafted Fascination plants inoculated with $F$. oxysporum $\mathrm{f}$. sp. niveum produced lower weights of marketable fruit than nongrafted Fascination not inoculated with $F$. oxysporum $\mathrm{f}$. sp. niveum $(P<0.0001)$ (Table 4$)$. Marketable fruit weights produced by nongrafted Fascination plants inoculated with $F$. oxysporum f. sp. niveum alone did not differ from plants inoculated with $F$. oxysporum f. sp. niveum and $M$. incognita together. Likewise, marketable weight produced by nongrafted Fascination inoculated with $M$. incognita alone did not differ from weights of fruit produced by noninoculated, nongrafted Fascination. Finally, marketable weights produced by nongrafted Fascination plants inoculated with $F$. oxysporum f. sp. niveum or $F$. oxysporum f. sp. niveum plus $M$. incognita were significantly lower than noninoculated, nongrafted Fascination, the no pathogen control treatment (Table 4). Thus, mean weight of marketable fruit from plants not inoculated with $F$. oxysporum $\mathrm{f}$. sp. niveum was $69.1 \pm 5.4 \mathrm{t} / \mathrm{ha}$, whereas mean weight of marketable fruit from plants inoculated with $F$. oxysporum $\mathrm{f}$. sp. niveum was only $24.9 \pm 5.8$ t/ha. Inoculation of nongrafted Fascination plants with $M$. incognita did not significantly affect marketable yield $(P=0.21)$.

Grafted Carnivor inoculated with $M$. incognita produced lower weights of marketable fruit than Carnivor not inoculated with $M$. incognita $(P=0.003)$. Mean weight of marketable fruit from plants not inoculated with $M$. incognita was $55.0 \pm 6.5 \mathrm{t} / \mathrm{ha}$, whereas mean weight of marketable fruit from plants inoculated with $M$. incognita was only $33.1 \pm 4.3 \mathrm{t} / \mathrm{ha}$. Weight of marketable fruit produced by grafted Carnivor inoculated with $F$. oxysporum $\mathrm{f}$. sp. niveum did not differ from that of noninoculated Carnivor (Table 4). Likewise, marketable weight did not differ between grafted Carnivor inoculated with $M$. incognita and $M$. incognita plus $F$. oxysporum $\mathrm{f}$. sp. niveum. Marketable weight produced by grafted Carnivor inoculated with $M$. incognita alone did not differ from noninoculated Carnivor, but marketable weight produced by Carnivor plants inoculated with both pathogens was lower than weight of noninoculated Carnivor. Mean marketable weight produced by Carnivor rootstocks inoculated with $F$. oxysporum f. sp. niveum did not differ from Carnivor rootstocks not inoculated with $F$. oxysporum $\mathrm{f}$. sp. niveum $(P=0.63)$.

When all 12 rootstock-pathogen treatment combinations were compared with each other, marketable weights of four treatments differed from noninoculated, nongrafted Fascination, which is the current standard treatment for managing Fusarium wilt: the two treatments in which Carnivor was inoculated with $M$. incognita and the two treatments in which nongrafted Fascination was inoculated with $F$. oxysporum f. sp. niveum (Tables 4 and 5). These latter four treatments did not differ from each other $(P=0.05)$. Marketable weights of the eight higher-yielding treatments that included all noninoculated treatments, all Carolina Strongback treatments, Carnivor inoculated with $F$.

Table 5. Analysis of variance outputs for the effects of rootstock and pathogen treatments on watermelon yields

\begin{tabular}{|c|c|c|c|c|}
\hline \multirow[b]{2}{*}{ Source of variation } & \multicolumn{2}{|c|}{$\begin{array}{l}\text { Marketable } \\
\text { weight (t/ha) }\end{array}$} & \multicolumn{2}{|c|}{$\begin{array}{l}\text { Total weight } \\
\text { (t/ha) }\end{array}$} \\
\hline & 2016 & 2018 & 2016 & 2018 \\
\hline Rootstock main effect & $0.359^{z}$ & 0.927 & 0.551 & 0.763 \\
\hline Pathogen treatment main effect & 0.716 & 0.002 & 0.665 & 0.002 \\
\hline $\begin{array}{l}\text { Rootstock by pathogen treatment } \\
\text { interaction }\end{array}$ & 0.993 & 0.0003 & 0.988 & 0.0001 \\
\hline
\end{tabular}

${ }^{\mathrm{z}}$ Probability of a greater $F$ value in analysis of variance.

Table 4. Yield of triploid watermelon fruit produced by grafted or nongrafted cultivar Fascination and coinoculated with Fusarium oxysporum f. sp. niveum and Meloidogyne incognita

\begin{tabular}{|c|c|c|c|c|c|c|}
\hline \multirow[b]{2}{*}{ Grafting } & \multirow[b]{2}{*}{ Rootstock } & \multirow[b]{2}{*}{ Pathogen treatment } & \multicolumn{2}{|c|}{$\begin{array}{c}\text { Marketable } \\
\text { weight }(t / h a)^{x}\end{array}$} & \multicolumn{2}{|c|}{ Total weight (t/ha) } \\
\hline & & & 2016 & 2018 & 2016 & 2018 \\
\hline None & None & None & $52.1 \mathrm{a}^{\mathrm{y}}$ & $64.8 \mathrm{ab}$ & $60.3 \mathrm{a}$ & $73.0 \mathrm{ab}$ \\
\hline None & None & M. incognita & $43.5 \mathrm{a}^{\mathrm{z}}$ & $73.4 \mathrm{a}^{\mathrm{z}}$ & $50.8 \mathrm{a}^{\mathrm{z}}$ & $84.9 \mathrm{a}^{\mathrm{z}}$ \\
\hline None & None & F. oxysporum & $45.0 \mathrm{a}$ & $20.7 \mathrm{e}$ & $61.5 \mathrm{a}^{\mathrm{z}}$ & $28.3 \mathrm{e}^{\mathrm{z}}$ \\
\hline None & None & M. incognita $+F$. oxysporum & $51.6 \mathrm{a}$ & $29.1 \mathrm{de}$ & $63.6 \mathrm{a}$ & $33.8 \mathrm{de}$ \\
\hline Grafted & Cultivar Carnivor & None & $38.5 \mathrm{a}$ & $53.3 \mathrm{abc}$ & $51.4 \mathrm{a}$ & $60.2 \mathrm{bc}$ \\
\hline Grafted & Cultivar Carnivor & M. incognita & $30.3 \mathrm{a}$ & 38.0 cde & $41.4 \mathrm{a}$ & 44.7 cde \\
\hline Grafted & Cultivar Carnivor & F. oxysporum & $27.1 \mathrm{a}$ & $56.7 \mathrm{abc}$ & $39.3 \mathrm{a}$ & $64.0 \mathrm{abc}$ \\
\hline Grafted & Cultivar Carnivor & $M$. incognita $+F$. oxysporum & $38.5 \mathrm{a}$ & $28.1 \mathrm{de}$ & $49.1 \mathrm{a}$ & $33.4 \mathrm{de}$ \\
\hline Grafted & Cultivar Carolina Strongback & None & $46.5 \mathrm{a}$ & $48.9 \mathrm{bcd}$ & $56.4 \mathrm{a}$ & $60.0 \mathrm{bc}$ \\
\hline Grafted & Cultivar Carolina Strongback & M. incognita & $42.0 \mathrm{a}$ & $43.5 \mathrm{bcd}$ & $48.9 \mathrm{a}$ & $53.8 \mathrm{bcd}$ \\
\hline Grafted & Cultivar Carolina Strongback & F. oxysporum & $48.5 \mathrm{a}$ & $43.8 \mathrm{bcd}$ & $58.4 \mathrm{a}$ & 51.9 bcde \\
\hline Grafted & Cultivar Carolina Strongback & M. incognita $+F$. oxysporum & $46.5 \mathrm{a}$ & $44.8 \mathrm{bcd}$ & $54.9 \mathrm{a}$ & $61.2 \mathrm{abc}$ \\
\hline
\end{tabular}

${ }^{\mathrm{x}}$ Unblemished fruit weighing $>4.54 \mathrm{~kg}$ a piece.

${ }^{y}$ Means within a column with the same letter are not significantly different: Fisher's protected least significant difference test, $P \leq 0.05$.

${ }^{\mathrm{z}}$ Means differ between years, $P<0.05$. 
oxysporum f. sp. niveum alone, and nongrafted Fascination inoculated with $M$. incognita alone did not differ from marketable weight produced by noninoculated, nongrafted Fascination (Table 4).

Because marketable fruit accounted for $\geq 69 \%$ of the weight of all fruit produced in each treatment combination in both years, significant differences among treatments for total weight of fruit were very similar to differences observed for weight of marketable fruit. In addition, total weight of Carolina Strongback inoculated with $F$. oxysporum $\mathrm{f}$. sp. niveum alone did not differ from nongrafted Fascination inoculated with $F$. oxysporum $\mathrm{f}$. sp. niveum alone (Tables 4 and 5 ).

Weight and number of cull fruit (i.e., fruit that was sunburned, damaged by wildlife, or affected by anthracnose) were very low in both experiments relative to the weight and number of cull fruit in other experiments done at the CREC reported in Keinath et al. (2019). Although number of cull fruit did not differ among treatments within years, when years were combined, the rootstock bypathogen treatment interaction was significant $(P=0.027)$. Among hosts inoculated with both $M$. incognita and $F$. oxysporum f. sp. niveum, grafted Carolina Strongback produced more cull fruit, 386 per hectare, than nongrafted Fascination, which had no cull fruit $(P=0.0005)$. The numbers of cull fruit did not differ among rootstocks inoculated with $M$. incognita alone, rootstocks inoculated with $F$. oxysporum f. sp. niveum alone, or rootstocks that were not inoculated (data not shown). Weight of cull fruit did not differ significantly among any treatments (data not shown).

Fruit sizes. Mean weights of individual fruits were $8.28 \pm 0.15$, $7.64 \pm 0.19$, and $7.76 \pm 0.19 \mathrm{~kg}$ for grafted Carolina Strongback, grafted Carnivor, and nongrafted Fascination, respectively. Mean fruit weight was greater for Carolina Strongback than for the other two grafting treatments $(P<0.05)$. Mean fruit weight in all three grafting treatments was greater than the optimum size for seedless watermelon fruit, $6.8 \mathrm{~kg}$ ( $t$ tests, $P=0.001$ ). However, only mean Carolina Strongback fruit weight was greater than the upper limit for 45 -count fruit $(7.9 \mathrm{~kg} ; P=0.05)$.

The distribution by size of marketable fruit (measured as individual fruit weight) differed in the 2 years $(P<0.0001)$ based on multivariate analysis of variance. In 2016, small, medium, large, and extralarge fruit represented 24.3, 29.6, 25.6, and $20.2 \%$ of all marketable fruit, respectively, whereas in 2018, the distribution was 19.6, 21.6, 24.9 , and $34.0 \%$, respectively. More medium fruits were produced in 2016 than in $2018(P=0.003)$, but more extra-large fruits were produced in 2018 than in $2016(P<0.0001)$. There were no significant interactions of rootstock or pathogen treatment with year $(P>0.05)$ for fruit size distribution.

Pathogen treatments affected the size of fruit produced by the different rootstock treatments (rootstock by pathogen interaction significant, $P=0.009$ ) (Fig. 2). In the noninoculated pathogen treatment, nongrafted Fascination produced more extra-large fruit than grafted Carnivor $(P=0.003)$, whereas grafted Carolina Strongback did not differ from the other rootstocks. In all three inoculated treatments, grafted Carolina Strongback produced a greater percentage of extra-large fruit than nongrafted Fascination $(P \leq 0.05)$. When rootstocks were inoculated with $M$. incognita with or without coinoculation with $F$. oxysporum f. sp. niveum, grafted Carolina Strongback also produced more extra-large fruit than grafted Carnivor $(P \leq$ 0.03 ). When rootstocks were inoculated with $F$. oxysporum $\mathrm{f}$. sp. niveum alone, grafted Carnivor produced a greater percentage of extra-large fruit than nongrafted Fascination $(P=0.04)$.

All four grafted Carnivor treatments and all three inoculated nongrafted Fascination treatments had lower percentages of extra-large fruit than noninoculated, nongrafted Fascination, the standard treatment, whereas the four grafted Carolina Strongback treatments did not differ from noninoculated, nongrafted Fascination $(P \leq 0.05)$. The percentage of small fruit was greater for nongrafted Fascination inoculated with both pathogens, noninoculated grafted Carnivor, and grafted Carnivor inoculated with $M$. incognita alone than for noninoculated, nongrafted Fascination. In addition, nongrafted Fascination and grafted Carnivor inoculated with $F$. oxysporum $\mathrm{f}$. sp. niveum produced greater percentages of medium fruit than noninoculated, nongrafted Fascination. The percentage of large fruit did not differ by rootstock or pathogen treatment.

Weight of extra-small fruit that did not reach the minimum marketable size for seedless watermelon (i.e., $4.5 \mathrm{~kg}$ ) did not differ among any treatments in either year ( $F$ values for treatment and the year by treatment interaction were not significant; $P=0.13$ and $P=0.37$, respectively). Grafted Carnivor produced more extra-small fruit in $2016(1.75 \mathrm{t} / \mathrm{ha})$ than in 2018 (0.90 t/ha), but weights did not differ between years for the other two rootstock treatments (data not shown).

\section{Discussion}

Resistance to $F$. oxysporum f. sp. niveum in interspecific hybrid squash Carnivor and citron Carolina Strongback was not affected by coinfection with $M$. incognita. Both rootstock genera Cucurbita and Citrullus expressed a high level of resistance to $F$. oxysporum f. sp. niveum when they were inoculated with $F$. oxysporum f. sp. niveum alone and with $F$. oxysporum $\mathrm{f}$. sp. niveum plus $M$. incognita. Based on the definitions of resistance to Fusarium wilt used by Martyn and McLaughlin (1983), both rootstocks are considered resistant, because the final incidence of wilted plants was $<20 \%$. This field study confirms results from our greenhouse study that showed retention of resistance to Fusarium wilt when interspecific hybrid squash rootstock Strong Tosa was inoculated with $F$. oxysporum $\mathrm{f}$. sp. niveum race 2 and M. incognita (Keinath and Agudelo 2018). In another greenhouse study, no differences in Fusarium wilt severity were observed when watermelon and interspecific hybrid squash were inoculated with $F$. oxysporum f. sp. niveum or $F$. oxysporum f. sp. niveum plus M. incognita (Seo and Kim 2017). In this study, each plant in the coinoculated treatments was inoculated with both pathogens, and therefore, the results are more reliable than observations based on plants grown in soil collected from fields with an unknown pathogen distribution (Sumner and Johnson 1973).

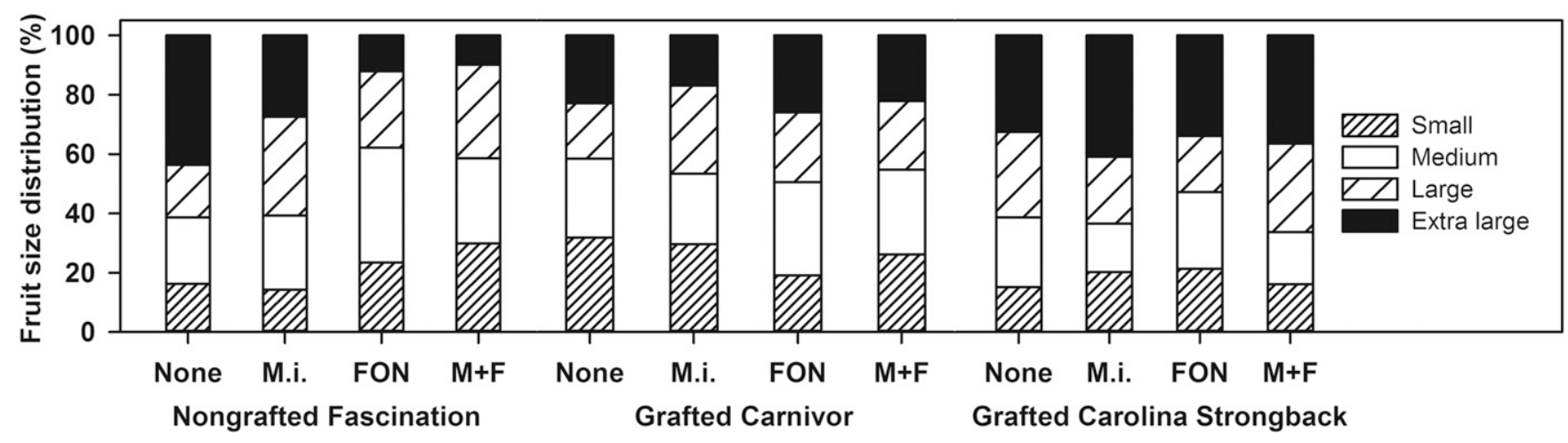

Fig. 2. Distribution of sizes of unblemished, triploid watermelon fruit weighing $>4.5 \mathrm{~kg}$ a piece produced by cultivar Fascination inoculated or not inoculated with Meloidogyne incognita (M.i.) and transplanted into plots infested or not infested with Fusarium oxysporum f. sp. niveum (FON) race 2 in 2016 and 2018 . M+F is the treatment with both pathogens. Fascination was not grafted, was grafted onto interspecific hybrid squash rootstock cultivar Carnivor, or was grafted onto citron rootstock cultivar Carolina Strongback. 
Final incidence rates of Fusarium wilt, AUDPC, and root galling were very similar in both years of this study. The lack of an effect of year was most likely owing to inoculating seedlings with $M$. incognita and $F$. oxysporum $\mathrm{f}$. sp. niveum so that all seedlings in the appropriate pathogen treatments were exposed to inoculum. The use of one isolate and two isolates of $F$. oxysporum f. sp. niveum in 2016 and 2018, respectively, had no measurable effect on Fusarium wilt. Likewise, distributing additional inoculum throughout the bed in 2018 rather than placing it only under the transplants as in 2016 had no effect on disease incidence or progression, although it may have contributed to the yield reduction observed in 2018. In addition, incidence of Fusarium wilt in treatments not inoculated with $F$. oxysporum f. sp. niveum was statistically identical between 2016 and 2018 . Thus, it seemed that the $F$. oxysporum $\mathrm{f}$. sp. niveum inoculum added in 2016 did not persist in the field until 2018. There also was no effect of year and no interactions with year for percentage of galling, although different levels and types of nematode inocula were used in the 2 years. Therefore, grafting or not grafting onto cucurbit rootstocks and inoculating or not inoculating with $F$. oxysporum $\mathrm{f}$. sp. niveum and $M$. incognita were the main treatment effects in these experiments.

As previously reported, interspecific hybrid squash was more susceptible to southern root knot nematode than citron or watermelon (Álvarez-Hernández 2015; Keinath and Agudelo 2018; Thies et al. 2010, 2015a, 2015b). In this study, citron and watermelon did not differ in susceptibility to $M$. incognita. In one previous study, watermelon and citron did not differ in susceptibility to $M$. incognita, whereas in three other studies, citron was less susceptible than watermelon (Álvarez-Hernández 2015; Thies et al. 2010, 2015a, 2015b). In this study, not only did the root system of Carnivor interspecific hybrid squash have a greater percentage of galling compared with watermelon, but also, the mass of the galls, indirectly measured as root weight, was greater. Root knot nematode galls on root systems of Carnivor appeared very similar to the galls on Strong Tosa illustrated by Thies et al. (2010).

Both $F$. oxysporum f. sp. niveum and $M$. incognita reduced yields of hosts that were susceptible to each pathogen in 2018 but not in 2016. F . oxysporum f. sp. niveum significantly reduced the weight of marketable-sized watermelon fruit harvested from nongrafted Fascination by $55 \%$ compared with Fascination grafted onto Carnivor. $M$. incognita significantly reduced the weight of marketable fruit harvested from Fascination grafted onto Carnivor rootstock by $49 \%$ compared with nongrafted Fascination. In both host-pathogen pairs, weights were reduced on the susceptible host in both treatments inoculated with the respective pathogen but not in the two treatments not exposed to added inoculum of the pathogen. Thus, there was no interaction between $F$. oxysporum $\mathrm{f}$. sp. niveum and $M$. incognita on watermelon yields. This lack of a yield response is additional evidence that these two pathogens do not interact on watermelon, interspecific hybrid squash, or citron (Keinath and Agudelo 2018; Seo and Kim 2017).

Rootstocks resistant to $F$. oxysporum $\mathrm{f}$. sp. niveum race 2 increased yields compared with susceptible nongrafted watermelon. In 2018, weight of marketable fruit produced by Fascination grafted onto Fusarium-resistant Carnivor or Carolina Strongback rootstock was increased by 121 or $78 \%$, respectively, compared with susceptible nongrafted Fascination inoculated with $F$. oxysporum f. sp. niveum. Increased yields from grafting Fascination onto Carnivor relative to nongrafted Fascination have been documented previously in fields naturally infested with $F$. oxysporum $\mathrm{f}$. sp. niveum race 2 (Keinath and Hassell 2014b). Grafting triploid watermelon susceptible to Fusarium wilt onto other cultivars of interspecific hybrid squash consistently increased total weight of fruit produced in Fusariuminfested soil (Álvarez-Hernández et al. 2015; Miguel et al. 2004). However, reduction in yields of seedless watermelon fruit grafted onto interspecific hybrid squash grown in fields infested with $M$. incognita also has been reported previously. A significant reduction in total weight relative to nongrafted watermelon was observed in three of seven field experiments done in two locations over several years, which is comparable with the one of two experiments in this study (Thies et al. 2010, 2015a, 2015b).
Yields of Fascination were similar to or slightly greater in this study than in a previous study of grafted Fascination also conducted at the CREC (Keinath and Hassell 2014b). Moreover, a greater percentage of extra-large fruit was produced in all rootstock-pathogen treatment combinations than is typical of nongrafted Fascination, of which one-half the fruit are expected to weigh between 6.2 and $7.9 \mathrm{~kg}$, the size of seedless watermelon preferred by produce brokers (Keinath et al. 2019). Mean weight of individual fruit was larger on citron rootstock Carolina Strongback than on interspecific hybrid squash Carnivor rootstock or nongrafted Fascination. In addition, grafted Carolina Strongback inoculated with $M$. incognita produced a greater percentage of extra-large fruit compared with grafted Carnivor and nongrafted Fascination inoculated with $M$. incognita. Grafted Carolina Strongback and grafted Carnivor also produced more extra-large fruit when inoculated with $F$. oxysporum f. sp. niveum compared with nongrafted Fascination (Fig. 2). In a Mexican field naturally infested with $F$. oxysporum f. sp. niveum and $M$. incognita, weights of individual triploid watermelon fruit also were greater on grafted cultivar Robusta citron and grafted cultivar Super Shintoza interspecific hybrid squash than on nongrafted watermelon, whereas fruit weights did not differ between the two rootstocks (Álvarez-Hernández et al. 2015). Likewise, a Fusarium-susceptible triploid scion grafted onto interspecific hybrid squash cultivar Shintoza and grown in F. oxysporum f. sp. niveum-infested soils in Spain consistently produced heavier fruit than nongrafted watermelon (Miguel et al. 2004).

One principle of sustainable agriculture is that practices implemented to increase sustainability of one part of an agricultural operation should not reduce the sustainability of another part. Grafting to manage Fusarium wilt is recommended when pressure from $F$. oxysporum f. sp. niveum is severe each year (Bertucci et al. 2018; Keinath and Hassell 2014b; Taylor et al. 2008). When interspecific hybrid squash rootstocks are used to graft watermelon, root knot nematode must be managed because of the risk of yield loss. Management likely will require application of fumigant or granular nematicides (Kemble et al. 2018; Thies et al. 2015 b). Carolina Strongback would be the preferred rootstock for growers to use in fields infested with both root knot nematode and $F$. oxysporum f. sp. niveum, because yields of Carolina Strongback, regardless of pathogen treatment, did not differ from noninoculated, nongrafted watermelon. Using a rootstock like Carolina Strongback that is resistant to both pathogens would eliminate the need for pesticide treatments for either pathogen. Because fruits of Fascination grafted onto Carolina Strongback were larger than optimal for the current market, cultural practices, like fertilization or spacing, may need to be adjusted so that the majority of fruit produced fall into the $6.2-$ to $7.9-\mathrm{kg}$ range (Álvarez-Hernández et al. 2015).

\section{Acknowledgment}

This work is Technical Contribution number 6703 of the Clemson University Experiment Station.

\section{Literature Cited}

Álvarez-Hernández, J. C., Castellanos-Ramos, J. Z., Aguirre-Mancilla, C. L. Huitrón-Ramírez, M. V., and Camacho-Ferre, F. 2015. Influence of rootstocks on Fusarium wilt, nematode infestation, yield and fruit quality in watermelon production. Cienc. Agrotec. 39:323-330.

Bertucci, M. B., Jennings, K. M., Monks, D. W., Schultheis, J. R., Perkins-Veazie, P., Louws, F. J., and Jordan, D. L. 2018. Early season growth, yield, and fruit quality of standard and mini watermelon grafted onto several commercially available cucurbit rootstocks. HortTechnology 28:459-469.

Branham, S. E., Levi, A., Farnham, M. W., and Wechter, W. P. 2017. A GBS-SNPbased linkage map and quantitative trait loci (QTL) associated with resistance to Fusarium oxysporum f. sp. niveum race 2 identified in Citrullus lanatus var. citroides. Theor. Appl. Genet. 130:319-330.

Davis, A. R., Perkins-Veazie, P., Sakata, Y., Lopez-Galarza, S., Maroto, J. V., Lee, S. G., Huh, Y. C., Sun, Z., Miguel, A., King, S. K., Cohen, R., and Lee, J. M. 2008. Cucurbit grafting. Crit. Rev. Plant Sci. 27:50-74.

Hussey, R. S., and Barker, K. R. 1973. Comparison of methods of collecting inocula of Meloidogyne spp., including a new technique. Plant Dis. Rep. 57: $1025-1028$. 
Keinath, A. P., and Agudelo, P. A. 2018. Retention of resistance to Fusarium oxysporum f. sp. niveum in cucurbit rootstocks infected by Meloidogyne incognita. Plant Dis. 102:1820-1827.

Keinath, A. P., Coolong, T. W., Lanier, J. D., and Ji, P. 2019. Managing Fusarium wilt of watermelon with delayed transplanting and cultivar resistance. Plant Dis. 103:44-50.

Keinath, A. P., and DuBose, V. B. 2009. First report of Fusarium oxysporum f. sp. niveum race 2 in South Carolina watermelon fields. Phytopathology 99:S63.

Keinath, A. P. and Hassell, R. L. 2009. On-farm evaluation of hairy vetch and fumigation for integrated control of Fusarium wilt on seedless watermelon, 2008. Plant Dis. Manage. Rep. 3:V035.

Keinath, A. P., and Hassell, R. L. 2014a. Control of Fusarium wilt of watermelon by grafting onto bottlegourd or interspecific hybrid squash despite colonization of rootstocks by Fusarium. Plant Dis. 98:255-266.

Keinath, A. P., and Hassell, R. L. 2014b. Suppression of Fusarium wilt caused by Fusarium oxysporum f. sp. niveum race 2 on grafted triploid watermelon. Plant Dis. 98:1326-1332.

Keinath, A. P., Hassell, R. L., Everts, K. L., and Zhou, X.-G. 2010. Cover crops of hybrid common vetch reduce Fusarium wilt of seedless watermelon in the eastern United States. Plant Health Prog. https://doi.org/10.1094/PHP-20100914-01-RS

Kemble, J. M., Meadows, I. M., Jennings, K. M., and Walgenbach, J. F., eds. 2018. Southeastern U.S. Vegetable Crop Handbook. https://www.growingproduce. com/southeasternvegetablecrophandbook/

Liu, Q., Zhao, X., Brecht, J. K., Sims, C. A., Sanchez, T., and Dufault, N. S. 2017. Fruit quality of seedless watermelon grafted onto squash rootstocks under different production systems. J. Sci. Food Agric. 97:4704-4711.

Madden, L. V. 1986. Statistical analysis and comparison of disease progress curves. Pages 55-84 in: Plant Disease Epidemiology, Vol. 1, Population Dynamics and Management. K. J. Leonard and W. E. Fry, eds. Macmillan Publishing Co., New York, NY.

Martyn, R. D. 2017. Fusarium wilt of watermelon. Pages 38-40 in: Compendium of Cucurbit Diseases and Pests, 2nd Ed., A. P. Keinath, W. M. Wintermantel, and T. A. Zitter, eds. American Phytopathological Society Press, St. Paul, MN.

Martyn, R. D., and McLaughlin, R. J. 1983. Effects of inoculum concentration on the apparent resistance of watermelons to Fusarium oxysporum f. sp. niveum. Plant Dis. 67:493-495.

Miguel, A., Varoto, J. V., San Bautista, A., Baizauli, C., Cebolla, V., Pascual, B., López, S., and Guardiola, J. L. 2004. The grafting of triploid watermelon is an advantageous alternative to soil fumigation by methyl bromide for control of Fusarium wilt. Sci. Hortic. (Amsterdam) 103:9-17.
Seo, Y., and Kim, Y. H. 2017. Pathological interrelations of soil-borne diseases in cucurbits caused by Fusarium species and Meloidogyne incognita. Plant Pathol. J. 33:410-423.

Shaner, G., and Finney, R. E. 1977. The effect of nitrogen fertilization on the expression of slow-mildewing resistance in Knox wheat. Phytopathology 67 1051-1056.

Smith, C. L., and Freeman, J. H. 2017. Assessment of watermelon rootstock resistance to Fusarium oxysporum f. sp. niveum when subjected to Meloidogyne incognita. HortScience 52:S73.

Smith, C. L., Freeman, J. H., Kokalis-Burelle, N., and Wechter, W. P. 2017 Screening cucurbit rootstocks for varietal resistance to Meloidogyne incognita and Rotylenchulus reniformis. HortScience 52:S73-S74.

Sumner, D. R., and Johnson, A. W. 1973. Effect of root-knot nematodes on Fusarium wilt of watermelon. Phytopathology 63:857-861.

Taylor, M., Bruton, B., Fish, W., and Roberts, W. 2008. Cost benefit analyses of using grafted watermelon transplants for Fusarium wilt disease control. Acta Hortic. 782:343-350.

Thies, J. A., Ariss, J. J., Hassell, R. L., Buckner, S., and Levi, A. 2015a. Accessions of Citrullus lanatus var. citroides are valuable rootstocks for grafted watermelon in fields infested with root-knot nematodes. HortScience 50:4-8.

Thies, J. A., Ariss, J. J., Hassell, R. L., Olson, S., Kousik, C. S., and Levi, A. 2010 Grafting for management of southern root-knot nematode, Meloidogyne incognita, in watermelon. Plant Dis. 94:1195-1199.

Thies, J. A., Ariss, J. J., Kousik, C. S., Hassell, R. L., and Levi, A. 2016. Resistance to southern root-knot nematode (Meloidogyne incognita) in wild watermelon (Citrullus lanatus var. citroides). J. Nematol. 48:14-19.

Thies, J. A., Bucker, S., Horry, M., Hassell, R. L., and Levi, A. 2015b. Influence of Citrullus lanatus var. citroides rootstocks and their F1 hybrids on yield and response to root-knot nematode, Meloidogyne incognita, in grafted watermelon. HortScience 50:9-12.

United States Department of Agriculture, Agriculture Marketing Service. 2006 United States Standards for Grades of Watermelon. https://www.ams.usda gov/sites/default/files/media/Watermelon_Standard\%5B1\%5D.pdf

Wechter, W. P., Kousik, C., McMillan, M., and Levi, A. 2012. Identification of resistance to Fusarium oxysporum f. sp. niveum race 2 in Citrullus lanatus var. citroides plant introductions. HortScience 47:334-338.

Wechter, W. P., McMillan, M. M., Farnham, M. W., and Levi, A. 2016 Watermelon germplasm lines USVL246-FR2 and USVL252-FR2 tolerant to Fusarium oxysporum f. sp. niveum race 2. HortScience 51:1065-1067.

Yetisir, H., Sari, N., and Yücel, S. 2003. Rootstock resistance to Fusarium wilt and effect on watermelon fruit yield and quality. Phytoparasitica 31:163-169. 